\title{
The continuing politics of mistrust: performance management and the erosion of professional work
}

\author{
Tanya Fitzgerald
}

For the past two decades schools and teachers in New Zealand and elsewhere have been the subject of and subjected to intense public scrutiny of their performance and professional activities. In effect, policy solutions have cast teacher and school performance as a 'problem' to be solved/resolved via the intervention of the State. Consequently, the policy remedy has been the introduction of audit mechanisms such as systems of performance management to define, regulate and control teaching and teachers. That is, the State has directly intervened in the professional work and activities of teachers based on the flawed assumption that teachers cannot be trusted and therefore require the intervention of the State and its agencies to ensure their performance is aligned with organisational objectives. And while one of the hallmarks of a profession and professional practice is adherence to a set of prescribed standards, performance management has rendered teachers accountable to the State, not professional peers. And, as this article outlines, this has served to de-professionalise teaching and teachers' work.

Keywords: performance management; audit culture; teacher’s work; de-professionalisation

\section{Introduction}

We live in dangerous times. The opening decade of the twenty-first century has been marked by increasing concern about public safety that has erupted over the emergence of a number of threats. This includes, but is not limited to, the threat posed by terrorism, the threat of political interference and the waging of war in countries seemingly disconnected from democracy and democratic processes, the threat of ecological and biological disasters such as global warming and the avian flu epidemic and, more recently, the threat of economic collapse due to volatile markets, fluctuating currencies and decreasing supplies of natural resources. Yet, in subtle and logical ways, the apparent 'commonsense' formulation of responses to these threats has become legitimised and normalised in our everyday lives and practices. ${ }^{1}$

Schools, as institutions of the State, are similarly under threat and face unprecedented challenges. There has been a gradual yet insistent erosion of trust in teachers and their profes-sional knowledge, autonomy and expertise. One of the new and emerging threats is the mistrust of the professions and professionals (this includes the teaching, medical and legal professions) and the consequent public certainty that the imposition of standards, targets, and accountability is the antidote. ${ }^{2}$ This has resulted in a bifurcated public policy response that has involved, in the first stage, the restructuring of schools and, in the second stage, the restructuring of the professions and professional work. And as the educational reform agenda of the late 1980s and 1990s in New Zealand and elsewhere demonstrated, teachers' compliance is

\footnotetext{
${ }^{1}$ See Michael W. Apple, Educating the 'Right' Way: Markets, Standards, God and Inequality (New York: RoutledgeFalmer, 2001) for a persuasive argument on the conservative right and the impact of the call for a return to a 'common' past and 'commonsense approaches'.

2 The historical and contemporary underpinning of calls for quality, standards and the audit regime is well covered by Apple, Educating the 'Right' Way.
} 
critical to ensure the delivery of this 'new' and 'improved' agenda. ${ }^{3}$ One of the ways to secure a level of direct and immediate commitment by teachers is via performance management policies and processes that describe and prescribe what ought to occur in schools (at an organisational level), in staff rooms (at a professional level) and in classrooms (at a pedagogical level). As this article argues, performance management, articulated and framed as one of the policy solutions to the espoused 'problem' of schools and teachers, has not alleviated mistrust but has intensified scrutiny and, as a result, sharpened this mistrust.

The first stage of these politics of mistrust was embedded in the radical restructuring of schools that occurred in New Zealand in the closing decades of the twentieth century. ${ }^{4}$ These reforms were premised on the assumption that schools had to become more fiscally efficient and effective. Although there was an implicit level of trust in schools, teachers and their communities in the devolved model of school self-management, in reality the continuing nature of centralised control has emphasised that neither schools nor teachers, at either an individual or collective level, can be trusted.

The State, however, could not be assured that teachers were be trusted to implement the reform agenda, a level of surveillance and public regulation was required to ensure that they were acting in expected ways. Hence, the evolution of agencies in New Zealand such as the Education Review Office (ERO) and the Teachers Council to define, regulate, audit, and sanction schools and teachers if they do not meet insistent requirements that are enshrined in policies that prescribe what teachers should and ought to accomplish. In other words, schools and teachers were identified as a policy problem and could not be trusted to exercise professional judgement and act in professional ways (and this includes professional accountability). Thus, public accountability replaced professional accountability and autonomy. ${ }^{5}$

The second stage of these politics of mistrust originated from public dissatisfaction with the teaching profession that provided 'evidence' that policy makers required in order to affect a policy solution. ${ }^{6}$ In response to these demands for public accountability, ongoing and concurrent performance management policies were systematically introduced to assess, evaluate, regulate and monitor teachers. One of the consequences of these regimes of performance management is that teachers, particularly those with labels such as 'senior manager' or 'middle manager', ${ }^{7}$ are required to act for and on behalf of the State as well as engage in multiple policy directives such as compulsory teacher registration, attestation and annual appraisals that determine what 'counts' as a good teacher. Not only then has the

\footnotetext{
${ }^{3}$ Alex Moore, Gwyn Edwards, David Halpin, and Rosalyn George, 'Compliance, Resistance and Pragmatism: The (Re) Construction of Schoolteacher Identities in a Period of Intensive Education Reform', British Educational Research Journal 28, no. 4 (2002): 551-65.

${ }^{4}$ I have argued this point in considerable detail elsewhere. See Tanya Fitzgerald, 'Remodelling Schools and Schooling, Teachers and Teaching’, in Modernising Schools: People, Learning and Organisations, ed. Graham Butt, Helen M. Gunter, and Hywel Thomas (London: Continuum, 2007), 163-75.

${ }^{5}$ See Tanya Fitzgerald, Howard Youngs, and Peter Grootenboer, 'Bureaucratic Control or Professional Autonomy: Performance Management in NZ Schools’, School Leadership and Management 23, no. 1 (2003): 91-105.

${ }^{6}$ Philip Capper and Rae Munro, 'Professionals or Workers?: Changing Teachers Conditions of Service', in New Zealand Education Policy Today, ed. Sue Middleton, John Codd, and Alison Jones (Wellington: Allen \& Unwin, 1990); Edward Fiske and Helen Ladd, When Schools Compete: A Cautionary Tale (Washington, DC: Brookings Institution Press, 2000).

7 These terms are used in New Zealand schools although there is a gradual shift away from 'manager' and 'management' to 'leader (for example middle leader) and leadership (for example the Senior Leadership team).
} 
professional work of teachers intensified, ${ }^{8}$ what 'counts' as a good teacher and good teaching has shifted from the profession to the managerial apparatus of the State (and this includes not only performance management policies but also those agencies which audit and report on the performance of teachers and schools). The shift in accountability from the profession to policy makers has imposed an audit culture ${ }^{9}$ that describes and prescribes what ought to occur in schools, staffrooms, and classrooms. Performance management is, I would argue, no less than a direct assault on the teaching profession and teachers as professionals. Indeed, there can be little doubt, the restructuring of schools and teaching has irrevocably changed the content and purposes of public education. ${ }^{10}$

In this article I firstly present an abbreviated history of the introduction of performance management in New Zealand against a backdrop of alleged concerns about teachers and teaching to surface an understanding of ways in which these policies continue to erode and corrode trust in teachers and their professional work. More specifically, I argue that the decreasing professional autonomy experienced by teachers about their work and pedagogic practices over the past two decades is situated in a period in which there was, and continues to be, increasing control by the State not only about what is taught but who can teach and under what conditions. The net effect of this decline in professional autonomy has been a marked shift from self-regulation to mandated regulation that has led to teachers becoming 'a technical workforce to be managed and controlled rather than a profession to be respected'. ${ }^{11}$ Thus, as illustrated by the New Zealand example, there has been a progressive yet unrelenting erosion of trust in the professional work of teachers. This shift has been accompanied by policy solutions that initially located schools as the 'problem', to the identification of teachers as the 'problem' to be remedied through performance management policies and practices. The increasing audit of teachers' performance could assure the State and its agencies that teachers' commitment to the seemingly 'new' and 'modern' practices of the self-managed school has been secured. Performance management has irrevocably fostered a counter-productive culture of mistrust that has simultaneously intensified and de-professionalised the professional work of teachers.

\section{An abbreviated overview}

In the past two decades, terms such as performance, standards, outputs, targets, accountabil-ity, choice, quality, improvement, and efficiency have littered the language of education policy and practice in New Zealand as well as elsewhere. ${ }^{12}$ In various and diverse fields such as education, health, public services and agencies (namely the police, fire department, local government) as well as consumer services (for example trains, buses, planes, and supermar-ket checkouts), 'standards' of service and delivery are publicly audited, collated and the information disseminated, presumably because it is deemed to be 'in the public interest'. ${ }^{13}$ From displays in places such as MacDonald's ‘Employee of the Month' awards ostensibly for service and meeting standards of delivery, to school audit reports on websites such as the Office for Standards in Education (OfSTED) in England or the ERO in New Zealand, to public lists on railway station walls in England that 'name and shame' those who failed to purchase a rail

\footnotetext{
8 This point has been well argued by John A. Codd, 'Educational Reform, Accountability and the Culture of Distrust', New Zealand Journal of Educational Studies 34, no. 1 (1999): 45-53.

9 See the work of Michael Power, The Audit Explosion (London: Demos, 1994).

10 Codd, 'Educational Reform'; David Hartley, 'Marketing and the Re-enactment of School Management', British Journal of Sociology of Education 20, no. 3 (1999): 309-23.

11 Sally Tomlinson, Education in a Post-welfare Society (Buckingham, UK: Open University Press, 2001), 36.

${ }^{12}$ Fitzgerald, 'Remodelling Schools'.

13 Apple, Educating the 'Right' Way.
} 
ticket, our everyday lives are recorded, audited and made public. Whether a teacher, train traveller, or school, harsh sanctions are imposed on those who do not conform to pre-ordained rules and regulations. ${ }^{14}$ To ensure that standards are met, performance is constantly monitored and reported, and supervisors or managers are afforded responsibility for both workers and their work. I wonder then how long it will take before classroom activ-ities are recorded just as telephone conversations are taped for ubiquitous reasons such as 'training' or 'quality' when contact is made with internet service providers, banks, insurance companies, or utility suppliers?

These forms of management practices are not new and have been an integral aspect of the way in which schools and teachers have been managed since the late 1980s. Performance management, an evaluative system ostensibly designed to standardise, regulate and control professional work, is not a 'modern' technique to control and define teachers and their work. As I have commented elsewhere, the inspection and examination of teachers in New Zealand can be traced to the introduction of compulsory schooling in $1877 .{ }^{15}$ Across 111 years, the performance of teachers was scrutinised by inspectors who were appointed under the aegis of regional boards of education. Notably, this level of inspection graded teachers but at the same time provided a mechanism of support for teachers and schools. This level of professional trust and autonomy could not, however, withstand the intense ambush that the neo-liberal reforms in the closing decade of the twentieth century delivered.

The educational reforms of 1989 were predicated on neo-liberal ideology that dictated the need for schools to adopt the tenets of business management practices and become fiscally efficient and effective business units. ${ }^{16}$ Hence, both accountability and responsibility for the performance of schools and teachers were redistributed to the local level and therefore provided the policy apparatus for schools and teachers to be 'named and shamed' if they failed to meet the required standards. The adoption of the structures and discourses of new public management without doubt delivered organisational efficiencies and, consequently, the introduction of mission statements, vision and values, strategic plans, marketing initiatives, and the auditing of teacher and school performance have reinforced the apparent rationality of structures and hierarchies. ${ }^{17}$ In New Zealand schools, performance manage-ment, professional development, competency and teacher registration are inextricably linked. On the one hand, the meshing of such systems could be expedient, on the other, this apparent commonsense approach provides a mechanism for the introduction of performance-related pay. ${ }^{18}$

\footnotetext{
14 Jill Blackmore and Pat Thomson, 'Just "Good and Bad News”? Disciplinary Imaginaries of Head Teachers in Australian and English Print Media', Journal of Education Policy 19, no. 3 (2004): 301-20.

${ }^{15}$ Tanya Fitzgerald, 'Potential Paradoxes in Performance Appraisal: Emerging Issues for New Zealand Schools', in Managing Teacher Appraisal and Performance: A Comparative Approach, ed. David Middlewood and Carol Cardno (London: RoutledgeFalmer Press, 2001), 112-24.

${ }^{16}$ Fiske and Ladd, When Schools Compete.

17 The effect of business management practices in New Zealand schools is highlighted by John Codd, 'Teachers as "Managed Professionals” in the Global Education Industry: The New Zealand Experience', Educational Review 57, no. 2 (2005): 193-206; Marian Court, 'Talking Back to New Public Management Versions of Accountability in Education', Educational Management Administration \& Leadership 32, no. 2 (2004): 171-94. For a discussion on new public management see Jonathon Boston, John Martin, June Pallot, and Pat Walsh, Public Management: The New Zealand Model (Auckland: Oxford University Press, 1996).

18 Although 'successful' attestation means an increase to the next salary level, there is not at present an overt system whereby teachers receive bonus payments for their work. However, what is less known is that principals in New Zealand schools received salary increments based on their implementation of performance management systems. As performance management was not optional, the payment of this additional money appears to be incongruous.
} 
Significantly, while teachers recognise that some form of professional accountability and responsibility is a core aspect of their work as professionals, teachers and their unions in New Zealand have, to date, resisted performance-related pay. ${ }^{19}$

Since 1997, schools have been required to introduce performance management systems and personnel policies to promote and sustain high levels of staff performance. ${ }^{20}$ The primary purpose of performance management was to provide 'a positive framework for improving the quality of teaching and learning' and that performance management systems were designed to be 'flexible', 'appropriate' within a 'minimum quality assurance and accountability framework' ${ }^{21}$ A direct consequence of this espoused belief was that appraisers would act as neutral agents of policy. Thus, teachers enacted policy directives in their role as either an appraiser or appraisee and were directly involved in managerial processes with their professional colleagues such as the setting of annual objectives that were aligned with organisational strategies, classroom observation, and formal discussions with colleagues with regards their performance against set criteria.

Mahony and Hextall correctly assert that performance management is a 'process which links people and jobs to the strategy and objectives of the organisation' ${ }^{22}$ Hence, perfor-mance management systems ensure a direct connection between teachers' work and organisational success. This in turn presupposes that teaching and learning can be regulated and reduced to input-output models. It is further possible that performance could be accelerated in an optimal set of circumstances. By its very nature, performance management disconnects professional and pedagogic practices, ${ }^{23}$ continues to de-professionalise teaching and teachers' work $^{24}$ and is the antithesis of what it means to be a professional and engage in professional work.

The year 1999 heralded the next level of audit and regulation with the introduction of the Professional Standards that further tightened control of teachers and their work. Artic-ulated as 'part of the Government's strategy for developing and maintaining high-quality teaching and leadership in schools and improving learning outcomes for students, ${ }^{25}$ these standards, with the byline Criteria for Quality Teaching, described the key elements of teacher performance and provided 'a base for assessing teachers' progress in relation to pay progression, competency and professional development'. ${ }^{26}$ In effect, both systems designed to assess the performance of teachers were aligned with organisational structures and managerial imperatives that were indicative of business management rather than educational practices. Labels such as 'leader', 'manager', 'appraiser', 'appraisee' were used to denote and reinforce formal relationships

\footnotetext{
19 See Fitzgerald, 'Potential Paradoxes' and Fitzgerald, Youngs, and Grootenboer, 'Bureaucratic Control'. The impossibility of meshing performance management and performance-related pay in the New Zealand context is also the subject of John O’Neill, ed., Teacher Appraisal in New Zealand: Beyond the Impossible Triangle (Palmerston North: ERDC Press, 1997).

${ }^{20}$ Ministry of Education, Performance Management Systems (Wellington: Learning Media, 1997).

21 Ibid., 1.

22 Pat Mahony and Ian Hextall, 'Performing and Conforming', in The Performing School, ed. Dennis Gleeson and Chris Husbands (London: RoutledgeFalmer, 2000), 177.

${ }^{23}$ This point is also well argued by Andy Hargreaves, Changing Teachers, Changing Times:

Teachers' Work and Culture in the Post Modern Age (London: Cassell, 1994); Mike Bottery, 'The Challenge to Professionals from the New Public Management', Oxford Review of Education 22 (1996): 179-97.

${ }^{24}$ Fitzgerald, Youngs, and Grootenboer, 'Bureaucratic Control'; Fitzgerald, 'Remodelling Schools'.

25 Ministry of Education, Professional Standards: Criteria for Quality Teaching (Wellington:

Government Printer, 1999), 5.

26 Ibid., 4.
} 
between teachers. ${ }^{27}$ And while this produced a 'managed' system and teachers as 'managed' professionals as Codd has commented, the long-term effect of these neo-liberal policies has been the erosion of professional work, knowledge and expertise. ${ }^{28}$ In other words, the State, in its employment contract with teachers, can identify, define and specify what ought to be taught (and conversely what should not be taught ${ }^{29}$ ) and insist, through performance management practices, that these demands are acknowledged, implemented, and formally recorded.

In the past two decades of educational reform, systems to regulate and control the work of teachers have become both legitimised and normalised in schools, not just in New Zealand but in Australia, England and North America. I would argue that the silent message that is being, and has been, relayed is that teachers cannot be trusted and therefore, they too must be subject to mechanisms of audit and surveillance. Moreover, the legislative pen ${ }^{30}$ has ensured that teachers have been reconstructed as the managers of reform and, more specifically, performance management has made certain that teachers conform to externally mandated performance measures and that they exercise a level of individual and professional self-control to achieve what is required. The hegemony of performance management is predicated not only on the potentiality of professional sanction but further presupposes that teachers are compliant and docile. Furthermore, the rhetoric of the 'professional' has been co-opted to ensure that systems designed to standardise, regulate and control professional work and activities reside outside of the auspices of professional bodies and association. At a surface level, performance management is seductive insofar as it provides the illusion of professional accountability. The accountability is, not to the profession, but to the State.

Performance management has delivered for self-managed schools the mechanism to align product (teaching and learning) with outcomes (student results and teacher perfor-mance). These policies of performance management require teachers to make judgements and monitor the performance of their professional colleagues. This is a new form of control in which the professional work of teachers is simultaneously de-professionalised via the regulation of performance and re-professionalised by placing responsibility for this mana-gerial work on other teachers. ${ }^{31}$ Thus, as Rose concludes, teachers act as neo-liberal professionals ${ }^{32}$ working for and on behalf of the State. Notwithstanding this point, as a form of assurance that teachers are acting in appropriate and mandated ways, agencies such as the ERO audit the performance management processes to appease their policy masters and mistresses that performance management systems are actively in place in schools.

Policy solutions such as performance management systems (and this includes registration, attestation for salary purposes and professional standards) have been introduced as a benign way in which to make judgements about teachers’ performance. More worryingly, these policy solutions are part of a deliberate strategy by the State to regain control of schools and schooling, teachers and teaching through the use of performance indicators. In much the same

\footnotetext{
27 The formalisation of line management structures and practices in schools is commented on by Horace Bennett, 'One Drop of Blood: Teacher Appraisal Mark 2', Teacher Development 3, no. 3 (1999): 411-28.

28 Codd, 'Teachers as "Managed Professionals"'; Fitzgerald, Youngs, and Grootenboer, 'Bureaucratic Control'.

29 On this point see Apple, Educating the 'Right' Way; Michael W. Apple, Official Knowledge (New York: Routledge, 1993).

30 See Government of New Zealand, Tomorrow's Schools: The Reform of Education Administration in New Zealand (Wellington: Government Printer, 1988). This was the policy document that underpinned the reform agenda.

31 See Fitzgerald, Youngs, and Grootenboer, 'Bureaucratic Control'.

32 Nikolas Rose, Governing the Soul: The Shaping of the Private Self (London: Routledge, 1989).
} 
way that the market calls for the commodification of products (and education is one such example), teachers' work has been reduced to measures that commodify what ought and should be accomplished. Consequently, there is, as Michael Fielding suggests, no sense of the collective in the individual pursuit of meeting goals and targets. ${ }^{33}$

In summary, in New Zealand teachers have been increasingly subjected to systems that assess whether they meet criteria for registration, evaluated against a set of professional standards to judge competence, attested for salary increments and appraised to review performance. Underpinning these bureaucratic attempts to control the teaching profession is the assumption that teachers cannot be trusted to implement the agenda of the State and therefore these management practices are justified as commonsense responses to the 'problem' teachers present. What remains unclear is the extent to which systems of compliance produce the type of results it anticipates and demands.

\section{Performance and standards}

The culture of performance that has been organised around notions of quality, outcomes, targets and improvement objectives has gained steady momentum since the late 1980s; although it has neither been a straightforward nor uncontested process. The culture of performance has been introduced and legitimated in schools through performance management systems that have defined, regulated, controlled and sanctioned the work of teachers. However, performance management is set against a backdrop of State concerns that teachers cannot be trusted and reductive assumptions that in order for schools, teachers and students to be 'successful', performance measures should and ought to be aligned with private market principles and practices. ${ }^{34}$ What remains concerning is that performance management, as a hegemonic set of practices, is designed to determine 'quality' and 'standards' that contribute to 'improvements', and is, accordingly, positioned as a commonsense response. ${ }^{35}$ Consequently, the mantra of accountability, audit, targets, outcomes, standards and measures of performance has been imposed on schools as a policy solution to the 'problem' of raising achievement and improving schools. Yet, adequate levels of resources have not been provided for schools despite unrelenting public demands for increased performance.

The introduction of performance management, and subsequent systems to attest and register teachers according to a pre-determined set of professional standards, ${ }^{36}$ was not accidental. As Gunter $^{37}$ and others have argued, performance management was no less than a strategy to ensure compliance with the reform agenda and that changes in organisational practice would occur within a limited time frame. Performance management was a manage-rial strategy that directly intervened, as was its intention, in ways in which schools were managed and led and was predicated on policy assumptions that it was possible to construct the 'good' teacher who would deliver certain predetermined outcomes. ${ }^{38}$ The underpinning logic of performance

\footnotetext{
33 Michael Fielding, 'Leadership, Personalisation and High Performance Schooling: Naming The New Totalitarianism’, School Leadership and Management 26, no. 4 (2002): 347-69.

34 John Clarke and Janet Newman, The Managerial State (London: Sage, 1997) argue the connection between private market principles as an efficient way to raise and improve standards.

35 Links between teachers' professional standards and narratives of quality assurance and improvement are outlined by Judith Sachs, 'Teacher Professional Standards: Controlling or Developing Teaching?', Teachers and Teaching 9, no. 2 (2002): 175-86.

36 Ministry of Education, Professional Standards.

37 Helen M. Gunter, Leaders and Leadership in Education (London: Paul Chapman, 2001).

38 The work of John Smyth and Stephen Ball is instructive here. See John Smyth, 'Teacher Development Against the Policy Reform Grain: An Argument for Recapturing Relationships in Teaching and Learning', Teacher
} 
management was that teachers could not be trusted to control and regulate their own profession and therefore the direct intervention of the State was required to ensure not only a level of public and transparent accountability by teachers for their work, but that those teachers who did not perform would be sanctioned, in much the same way as those who had not complied with performance measures in train stations, airports, fast food counters, and supermarket checkouts as I have already outlined.

A secondary advantage that systems of performance management offered was a direct assurance that teachers were performing and conforming to the reform objectives. Thus, it was, I would suggest, critical for a strong State to be able to define, regulate and control teachers and teaching. Performance management was the mechanism that disconnected teachers from professional accountability and connected them with systems that called for self-regulation. The management of teachers' performance is, no more or no less than, the management of teaching. In an attempt to connect performance management with the professional work of teachers, policy narratives and practices have been increasingly concerned with aligning teachers' work as leaders with the practices of new managerialism. One of the immediate ways in which this was achieved was to ensure that labels such as 'middle leader', 'senior manager' or 'head of department' were attached to tasks such as the allocation, management, auditing and assessment of the work of other teachers. ${ }^{39}$ That is, the professional responsibilities of educa-tional leaders have become acutely connected with positional status and in the case of New Zealand, contractually mediated through remuneration and job descriptions that set forth the required (and desired) skills and abilities of the modern leader.

The rhetoric of standards and improvement has been used to pacify public demands, on the one hand $^{40}$, and, on the other, to ensure teacher responsiveness to performance manage-ment policies and practices that measured their productivity (in terms of student results) and performance. Such systems that emphasise efficiency and accountability accentuate the role of teachers as technicians rather than as professionals that presuppose that teachers cannot be trusted to establish and adhere to their own codes of professional conduct. The underpinning premise is that teachers are primarily motivated by extrinsic rewards and therefore cannot be trusted to serve the common good. Compliance and adherence to managerial demands of the State is therefore secured through performance agreements and performance management that control, regulate and discipline through testing, accountability, standards, outcomes and quality assurance processes. This continuing lack of trust in teachers, manifested in what Hemmings refers to as a deepening crises of respect, ${ }^{41}$ is damaging. ${ }^{42}$

Development 11, no. 2 (2007): 221-36; Stephen Ball, 'The Teacher’s Soul and the Terror of Performativity', Journal of Education Policy 18, no. 2 (2002): 215-28.

${ }^{39}$ Helen M. Gunter and Tanya Fitzgerald, 'Leading Learning and Leading Teachers: Challenges for Schools in the 21st Century’, Leading and Managing 13, no. 1 (2007): 1-15

40 The politics of reform and the apparent public dissatisfaction with the teaching profession has been the subject of intense debate. See, for example, Martin Thrupp, 'Exploring the Politics of Blame: School Inspection and its Contestation in England and New Zealand', Comparative Education 34, no. 2 (1998): 195-208. See also John Smyth, 'Undamaging 'Damaged' Teachers: An Antidote to the Self-managing School', Delta: Policy and Practice in Education 55, nos. 1-2 (2003): 3-30.

41 Annette Hemmings, 'Fighting for Respect in Urban High Schools’, Teachers College Record 105, no. 3 (2003): 416-37.

${ }^{42}$ The damaging effects of educational policy that is founded on misinformation and marginalised teachers is well argued in John Smyth, 'Policy Research and "Damaged Teachers": Towards an Epistemologically Respectful Paradigm’, Waikato Journal of Education 10 (2004): 263-81. 
John Smyth has argued that the replacement of leadership that is embedded in pedagogic practices with forms of managerialism is no less than a corruption of leadership. ${ }^{43}$ This level of regulation has resulted in the colonisation of teachers' work and professional activities and arguably directed their attention away from pedagogy and pedagogic practices. ${ }^{44}$ Education policy and practices that promote the audit and surveillance of teaching are, in my view, misplaced. The attention should be on ways in which productive pedagogy and productive practices occur; not solely on outcomes. ${ }^{45}$ Despite almost two decades of educa-tional reform there is little evidence to suggest that school self-management has produced improvements in teaching and learning. Perhaps it is time to suggest that the State cannot be trusted to deliver its objectives.

In much the same way that the number of items that pass through the checkout operator's hands might be counted, ${ }^{46}$ marks in examinations as well as other indicators such as increases (or decreases) in literacy and numeracy levels are used to make judgements about a teacher's performance. This is not to suggest that higher education has 'escaped' this panoptic surveil-lance and disciplinary regimes ${ }^{47}$ as exercises such as the Research Assessment Exercise (RAE) in England and the Performance Based Research Fund (PBRF) in New Zealand testify. In addition, discourses such as 'quality assurance', 'reporting', 'inspection', and 'improve-ment' are co-opted as disciplinary measures to ensure that the 'right' things are being done in the 'right' way. The 'right' way, and I do not use this term accidentally, is, in my view, no less than a mechanism to de-professionalise teachers and teaching so not only are they reconstructed as managed professionals ${ }^{48}$ but that schools and students are also managed in particular ways and their 'performance' regulated via OfSTED, ERO, league tables, and public attention. These are the terrors of performativity ${ }^{49}$ (what is produced, observed, and measured). ${ }^{50}$

The bureaucratisation of our everyday personal and professional lives and mechanisms of accountability with regards to performance appear to have been unquestionably accepted as the 'right' thing. Invariably too how we might act and react to a variety of circumstances in our professional lives is disciplined insofar as we 'perform' as if we are being watched at every point. It would seem that the threat of failure has effectively created a fear that resistance might result in public 'naming and shaming'. If the intention of policy was to create standards by which teachers could be judged, it is misplaced as teachers as professionals are required to submit to policy imperatives that prescribe how they ought to act and react; the technologies of performance which: 'present themselves as techniques of restoring trust (ie accountability, transparency and democratic control) ... as such, they presuppose a culture of mistrust in professions and institutions that they themselves contribute to, produce and intensify'. ${ }^{51}$

\footnotetext{
43 John Smyth, 'Unmasking Teachers' Subjectivities in Local School Management', Journal of Education Policy 17, no. 4 (2002): 463-82.

${ }^{44}$ See, from example, Pat Mahony and Ian Hextall, Reconstructing Teaching (London: RoutledgeFalmer, 2000).

45 This is more fully explored by Bob Lingard, Debra Hayes, Martin Mills, and Pam Christie, Leading Learning: Making Hope Practical in Schools (Maidenhead, UK: Open University Press, 2003).

${ }^{46}$ Charles Fishman, The Wal-Mart Effect: How an Out-of-Town Superstore Became a Superpower (London: Allen Lane/Penguin Books, 2006).

47 Jane Perryman, 'Panoptic Performativity and School Inspection Regimes: Disciplinary Mechanisms and Life under Special Measures’, Journal of Education Policy 21, no. 2 (2006): 147-61.

48 Codd, 'Teachers as "Managed Professionals"'.

49 Ball, 'Teacher's Soul'. This term is attributed to Jean Francois Lyotard, The Postmodern Condition: A Report on Knowledge, vol. 10 (Manchester: Manchester University Press, 1984).

50 Gleeson and Husbands, Performing School.

51 Mitchell Dean, Governmentality: Power and Rule in Modern Society (London: Sage, 1999), 169.
} 
In other words, policies of performance management are premised on the assumption that teachers cannot be trusted to exercise professional judgement and must therefore be presented with standards and performance measures that script and prescribe what they should and ought to do. Thus, the State and not the profession, determines what 'counts'. This is misplaced policy and it has irrevocably changed the nature of public schooling and teachers work as I have argued at an earlier point. ${ }^{52}$

There can be little doubt that performance management is concerned with ensuring effectiveness in classrooms (judged by measures such as literacy and numeracy tests and examination results) and efficiency at an organisational level (judged by the deployment of resources to meet organisational goals and demands). Effective leaders and effective schools act in particular ways ${ }^{53}$ and alongside other regimes such as school inspections, these levels of audit, surveillance and public reporting of performance have become normalised and both accepted and acceptable. This unrelenting focus on performance and standards, rules and regulations has, in complicated ways, interrupted the professional work of teachers. As I argue in the next section, the continuing mistrust of teachers has stimulated the production of a new form of professionalism in which teachers, as 'managed professionals' ${ }^{54}$ undertake their work within prescribed boundaries that are positioned as 'commonsense' approaches to teaching and learning.

\section{Managing teachers and teaching}

For almost two decades schools in New Zealand and England, although not exclusively or uniformly, have experienced the impact (and threat) of managerialism and modernisation that has served to change the nature of schools (as organisations) and teachers (as profes-sionals). The rhetoric of site-based management was used to seduce teachers, schools and communities that local decision making was both possible and permissible. At one level there were a number of structural changes that occurred to provide schools with a level of administrative responsibility and accountability yet, on the other, increasing surveillance of the work of teachers, schools and their governing bodies through inspection and systems such as performance management, ensured that a level of centralised control remained. ${ }^{55}$ The introduction of regulation and performance management placed increasing emphasis on public accountability of teachers via the creation of a managed profession. ${ }^{56}$ As I have outlined, the teaching profession in New Zealand has increasingly been subjected to polices and strategies of surveillance that have served to introduce a culture of managerialism and performativity. ${ }^{57}$ Rhetoric suggests that these policies have been underpinned with the desire to create 'a positive framework for improving the quality of teaching and learning' ${ }^{58}$ This is no less than blatant neo-liberal discourse wrapped up in the blanket of 'commonsense' that Apple

\footnotetext{
52 See John Smyth, Alistair Dow, Robert Hattam, Alan Reid, and Geoffrey Shacklock, Teachers' Work in a Globalizing Economy (London: Falmer, 2000), which outlines the impact of educational reform on teaching and teachers' professional work and identity.

53 See, for example, the work of Pam Sammons, Josh Hillman, and Peter Mortimore, Key Characteristics of Effective Schools: A Review of School Effectiveness Research (London: Institute of Education, 1995). The work of researchers in this area has gained ascendancy in recent times as schools search for eternal solutions in the quest for improved performance by students, teachers and the organisation.

54 See Codd, 'Teachers as "Managed Professionals"', on this point.

${ }^{55}$ Fitzgerald, 'Remodelling Schools'.

56 Codd, 'Teachers as "Managed Professionals",

57 Jenny Ozga, ‘Education: New Labour, New Teachers’, in New Managerialism, New Welfare?, ed. John Clark, Sharon Gewirtz, and Eugene McLaughlin (London: Sage, 2000).

58 Ministry of Education, Professional Standards, 1.
} 
speaks about; ${ }^{59}$ a blanket that masks official policy attempts to define and control what counts as teaching and learning. ${ }^{60}$ Not only then are teachers being audited through performance management practices that determine what they should know and be able to do, the adherence to specific curricula and assessment materials further defines what students ought to know and do. Here again I would like to draw attention to two critical questions that Michael Apple continues to ask: Whose knowledge is of most worth? And for what purposes is this official knowledge defined? ${ }^{61}$

These policy changes have produced a new climate in which teachers work; teachers now experience increased hours, increased class sizes, increased administrative tasks, greater accountability and more complex mechanisms for reporting teacher and student outcomes. ${ }^{62}$ This has led to a sense of loss of professional autonomy and independent judge-ment about pedagogy and pedagogic practices. In effect, the State has continued to weaken the education profession through surveillance and control mechanisms that standardise and prescribe what teachers ought to accomplish. Furthermore, the codification of teacher prac-tices as outlined in the Professional Standards has introduced a skill hierarchy between teachers (classified as 'beginning', 'classroom' and 'experienced'), 'unit holders' (teachers with additional leadership and management responsibilities and senior leaders (deputy prin-cipals and principals). ${ }^{63}$ It is highly doubtful as to whether performance management systems, designed to produce more professional and autonomous teachers, will achieve these purposes when, in reality, these are new (seemingly modernised) methods of organi-sational surveillance, control and conformity. ${ }^{64}$ Secondly, although there is no singular defi-nition of what constitutes a 'profession', one of the hallmarks of a profession is the centrality of ownership of knowledge, autonomy and responsibility, ${ }^{65}$ as well as a marked absence of hierarchical forms of self-control and the existence of self-regulatory processes. Yet, under regimented policies and practices of performance management, professional autonomy and responsibility is not possible. At the core of these policies and practices is the desire by the State and policy makers to construct a particular set of knowledge, skills, values and attributes for teachers and the profession of teaching. This is the new profession-alism that disconnects teachers from pedagogic practices. ${ }^{66}$

The emphasis on hierarchy and regulation has extended to the principalship/headship.

Educational reform, while espousing that the principal/head was the professional leader of the school, ${ }^{67}$ simultaneously positioned the principal/head as a worker of the managerial State with responsibility and accountability for teacher performance, levels of student achievement, fiscal and strategic management, school improvement initiatives, education policy and legislative compliance as well as overall school performance as determined by the ERO. Accordingly, the principalship has been reformed and additional training and qualifications have assisted with

\footnotetext{
59 Apple, Educating the 'Right' Way.

60 This point is also well argued by John Smyth, 'The Politics of Teachers' Work and the Consequences for Schools: Some Implications for Teacher Education', Pacific Journal of Teacher Education 34, no. 3 (2006): 30119.

${ }^{61}$ Apple, Official Knowledge, well documents these arguments.

${ }^{62}$ Fitzgerald, 'Remodelling Schools'

63 Ministry of Education, Professional Standards.

64 Fitzgerald, 'Remodelling Schools'.

65 John Furlong, Len Barton, Sheila Miles, and Geoff Whitty, Teacher Education in Transition (Buckingham, UK: Open University Press, 2000).

66 Clarke and Newman suggest that a new managerialism that calls for teachers to be more accountable and efficient and engage in change strategies has emerged. See Clarke and Newman, The Managerial State.

67 Government of New Zealand, Tomorrow's Schools, 10.
} 
producing the modern leader; a leader that is inevitably gendered, raced and classed. ${ }^{68}$ Notwithstanding this point, principalship is subject to intense scrutiny and located as the solution to raising school, teacher and student performance. ${ }^{69}$

Increasingly what is being produced via performance management mechanisms are highly regulated models of what constitutes a 'good' teacher and a 'good' leader; 'good' teachers and leaders who inevitably contribute to the production of 'good' workers and global citizens. As I have outlined in this article, since 1989 the nature of teachers' work and teaching has shifted considerably; from an emphasis on nation building and citizenship ${ }^{70}$ to a focus on the knowledge economy and the production of knowledge-based societies. Schooling has therefore mutated from a way of preparing young people for broader purposes (such as participation in a democratic society) to a mechanism of selection and preparation for the local and global labour market. In other words, the unquestioned purpose and responsibility of schools is to provide the workforce necessary to compete in the global economy.

To ensure that the needs of the economy and global market place are met, teachers' work has been reorganised 'in such a way as to facilitate the kind of outcome that is required by the State ${ }^{, 71}$ The curriculum, one of the key areas that was not devolved to local schools in 1989, not only prescribes what teachers ought to do but also determines what 'counts' as official knowledge. In other words, 'good' students will learn 'good' knowledge from 'good' teachers and get 'good' jobs. For this to occur, the agency of teachers has been co-opted to engage in economic and identity work on behalf of the State. The control of teachers' work and ways in which they act (or react) is central to assure the State that 'good' students with 'good' knowledge are being produced. Smyth and his colleagues ${ }^{72}$ suggest that there are five particular strategies that contribute to the engineering of compli-ance and consent from teachers: ${ }^{73}$

1) Regulated market control creates a situation whereby consumers (parents) exercise their economic choices and select a 'good' school for their child; a school that performs to expectations and which has captured market advantage through its own policies and practices. Accordingly, performance management systems as well as public reports from the ERO provide evidence that the school, and its teachers, are meeting their objectives. Not only then is teacher performance subject to scrutiny at an individual level (via his/her line manager), at a school level (via the attestation and registration of teachers), the community can also be assured that teachers and their performance are regularly scrutinised. The politics of fear and safety, as alluded to at an earlier point in this article, are therefore played out in numerous ways for the individual, organisation and community.

2) Technical control is exerted through the specification of what is taught (curriculum), how this will be taught (pedagogy) and student outcomes (assessment). In addition, curriculum changes have been from knowledge production to the acquisition of skills; skills that might not necessarily be taught by professionals. In other words, schools are, in the words of the Ministry of Education, future proofed. ${ }^{74}$ Or, is it simply the case that

\footnotetext{
68 Jill Blackmore, Troubling Women: Feminism, Leadership and Educational Change (Buckingham, UK: Open University Press, 1999).

69 Blackmore and Thomson, “"Good and Bad News”?'.

70 Apple, Official Knowledge.

71 Smyth et al., Teachers' Work, 26.

72 Smyth et al., Teachers' Work.

73 An earlier version of this analysis appears in Fitzgerald, 'Remodelling Schools'.

74 Ministry of Education, Education Priorities for New Zealand (Wellington: Ministry of Education,
} 
schools are teacher proofed? One of the mechanisms to ensure that teachers conform to pre-ordained practices is performance management which serves to reassure the organisation and the State that prescribed routines, policies and practices are being implemented. Performance management is, as I have emphasised in an earlier section, the management of teaching.

3) Bureaucratic control and the bureaucratisation of teaching and teachers' work ${ }^{75}$ are imperative to the production of the kinds of outcomes required by the State. Systems such as teacher registration, standards, codes of conduct, attestation and performance management inform the State and its agencies such as the ERO that teachers are performing in expected ways. This level of managerial control and accountability is central to the de-professionalisation of teaching and the determination of what 'counts' and how this counting will occur.

4) Corporate control is a process whereby the governance, management and organisation of schools are derived from the principles and practices of business management as I have outlined at an earlier point. In particular, systems of performance management are the ideal way in which the State can be assured that teachers are both instruments of, instrumental in, and critical to the adoption of neo-liberal reforms.

5) Ideological control is a more subtle process that seeks to advance particular views about what counts as 'good' teaching and being a 'good' teacher. Provided that teachers accept this official knowledge, ${ }^{76}$ can produce 'good' students' with 'good' knowledge and collaborate in processes such as performance management which are designed to monitor and judge the standard of their work, then ideological control can be asserted.

What appears missing from policy or any of the documents cited is coherent, robust and independent evidence that evaluates why systems of surveillance, regulation and audit of teachers' work and teaching are required. And indeed, despite two decades of monitoring and surveillance of the performance and standards attained by teachers, students, and schools, there is little or no evidence to suggest that anything has 'improved'. In effect, solutions are proposed and implemented in disciplinary ways, when a clearly identified 'problem' does not appear to exist, or at the very least, does not appear to have surfaced. I would like to casually suggest at this point that the introduction of performance and standards is no less than a policy solution and intervention in search of a problem.

\section{Speaking back}

One of the consequences of the economic processes and pressures of the market has been that a great deal of the labour has shifted to the consumer. That is, consumers are now required to be able to assemble furniture items, install computers, scan their own grocery items, make accommodation and travel bookings online, manage their banking electronically, as well as understand advertising and make sense of the information that is packaged with all these 'products'. In a quest to make these products more comprehensible and to assist consumers with their decisions, information is readily available that rates goods, services, and products. In much the same way, ERO reports and league tables of examination results reduce school and teacher performance to 'bite-size' chunks of information for the consumer to collect, collate and

1993).

${ }^{75}$ Fitzgerald, Youngs, and Grootenboer, 'Bureaucratic Control'.

${ }^{76}$ Apple, Official Knowledge. 
utilise in their decision-making processes. Thus, in much the same way as consumers require guarantees and protection from producers and their products, so too can teachers not be trusted unless measurable public results are provided and readily available. Consequently, there is the increasing pressure to perform according to imposed and reductive standards that have radically altered the way in which teachers experience their everyday work. Yet (some) teachers are, to an extent, complicit; their own career and professional and advancement depend on the expansion of their expertise as managers (of staff, curricula, and the organisation), their willingness to adopt performance management practices and their ability to demonstrate their responsiveness to schools (product) and parents/students (consumers). Or should a more subtle reading of the current situation be promulgated? That is, teachers act as managers and implement policies such as performance management that originate from the neo-liberal reform agenda precisely because they do not want 'others', presumably those committed to managerial impulses, to be recruited and engaged in these kinds of roles and duties in schools. And as I have commented elsewhere, it is possible that teachers can and do act in professional ways in their performance management practices. ${ }^{77}$

As I have argued to this point, performance management delivered the policy solution to the espoused lack of public confidence. One of the ideological foundations of Tomorrow's Schools was that teachers and schools required 'managing' in order for them to become more responsive to the emerging economic climate of the late 1980s. In effect, teachers have been removed from public debate (as have parents, communities and students) and are now required to deliver organisational objectives; objectives that are linked with the demands of the global market place and economic capital. Have teachers become complicit or compliant? Or has performance management reconstructed teachers as obedient and compliant individuals who cannot be trusted to act in professional ways?

There can be little doubt that while, on the one hand, an audit culture such as that which currently exists in schools heightens accountability yet, on the other, this audit culture simultaneously distorts the very nature of what it means to be a professional, belong to a profession, and engage in professional work. The increasing control of the professional work of teachers fosters less, rather than more, trust between professionals and the wider community. But to whom are teachers professionally accountable? In the first phase of reform, the educational reforms were predicated on the call for the public accountability of teachers. Yet, paradoxically, performance management requires teachers to be accountable to the State. How does this then, if at all, restore public confidence and trust in the profession? In what ways, if at all, can accountability enhance rather than diminish trust in the teaching profession? And what is the role of teachers as professionals and academics as professional researchers in speaking back?

The absence of public debate about policies such as performance management under-scores my earlier comments about the dangerous times in which we currently live. What appears to be occurring is that 'commonsense' approaches to education policy and policy making are constructed as logical ways to proceed; or at best (or worst), these processes are portrayed as sensible and logical primarily because they are inextricably linked with public demands for accountability. Thus, the creation and maintenance of sustained public debate is seemingly more difficult. Hence, the following can be read as a reasonably prophetic statement:

77 Fitzgerald, Youngs, and Grootenboer, 'Bureaucratic Control'. 
The culture in which we live is perhaps the most claustrophobic that has ever existed; in the culture of globalization ... there is no glimpse of an elsewhere, of an otherwise ... The first step towards building an alternative world has to be a refusal of the world picture implanted in our minds ... Another space is vitally necessary. ${ }^{78}$

In the foreseeable future, I do not envisage that the hegemonic culture and practices of performance management will abate. Indeed, one of the enduring legacies of this new professionalism around what 'counts' as 'good' teaching and learning as I have outlined, is that teachers can determine and calculate their worth. How teachers within an evaluative system may have co-opted these calculative practices is worthy of fuller exploration. As well, the extent to which teachers have used calculative practices to reinterpret their pedagogical practices and choices could also be rich areas of research. I am tendering the suggestion therefore that the policy imperatives such as performance management are not experienced or enacted in universal ways.

Research has been conducted as to ways in which teachers have responded to educational reform. ${ }^{79}$ However, these studies could be complemented by fine-grained ethnographic stud-ies that seek to understand the everyday work and professional identities of teachers within an intensified reform agenda; an agenda that increasingly seeks to locate the private sector and its practices as highly desirable.

What I am indicating here is that I fervently believe that teachers are not fully complicit in the de-professionalisation if their work, activities and identities. Recent work conducted by Michael Fielding, ${ }^{80}$ John Smyth, ${ }^{81}$ as well as Bob Lingard and colleagues, ${ }^{82}$ has indi-cated that teachers can and do speak back to policy narratives. As Helen Gunter and I have argued, ${ }^{83}$ the change that has to occur in schools is not just solely structures and hierarchy but that a return to pedagogy and pedagogic relationships are vital. This will therefore require teachers to speak back to policy imperatives and to have the professional courage and conviction to stand up and defend the ethical, moral and pedagogical imperatives on which public (that is, State) schools and schooling were founded.

\section{Conclusion}

There can be little doubt that our everyday personal and professional lives are subject(ed) to control, regulation, monitoring, surveillance and audit activities. The twenty-first century has already been marked with an almost obsessive focus on knowing what individuals do, where and how their activities are conducted and with whom, and imposing sanctions on those who do not conform. As I have pointed out in this paper, there are a number of control forces in play that have transferred autonomy and self-regulation from teachers to the State and the global market place. I would argue too the rhetoric of 'self-management' was co-opted to seduce and mislead teachers, schools and communities that they had a real and authentic opportunity to lead and manage their schools. The emphasis on standards and performance of teachers,

\footnotetext{
78 John Berger, The Shape of a Pocket (London: Bloomsbury Publishing, 2002), 214.

79 See for example Smyth, 'Unmasking Teachers' Subjectivities'; Sharon Gewirtz and Stephen Ball, 'From Welfarism to New Managerialism: Shifting Discourses of School Leadership in the Education Marketplace', Discourse 21, no. 3 (2000): 253-67.

80 Michael Fielding, 'Putting the Hands around the Flame: Reclaiming the Radical Tradition of State Education', Forum 47, nos. 2-3 (2005): 61-9.

81 Smyth, 'Teacher Development'.

82 Lingard et al., Leading Learning.

83 See, for example, Gunter and Fitzgerald, 'Leading Learning'.
} 
students and schools, and the increasing powers of agencies such as the ERO and OfSTED would suggest that 'self-management' is a highly centralised system that has led to the bureaucratisation of teachers and teaching. ${ }^{84}$ A cynical glance at the New Zealand landscape as portrayed in this article could cause one to wonder if the agenda of the State and its policy makers was to directly makeover schools or takeover the professional work of teachers. ${ }^{85}$ Performance management cannot, by its very nature, produce either a trustworthy profession or stimulate trust in the profession. What is required is a form of professional accountability that rests on the moral and ethical agency of teachers. For this to occur, responsibility and accountability for teachers and their professional work must lie with the profession itself. High trust accountability is both possible and permissible if professional ethics shape and define what constitutes the 'profession' and 'professional' work. This will necessarily involve the teaching profession 'speaking back' and becoming more actively involved in the re-professionalisation of teaching. This therefore requires a reconstruction of teacher professionalism as suggested by Carr and Hartnett:

...the professionalism of teachers is based on the recognition of their right to make autonomous judgements about how, in particular institutional and classroom contexts, to develop their students' capacity for democratic deliberation, critical judgement and rational understanding. Without this kind of professional autonomy teachers have no protection against external coercion and pressure, and they quickly become neutral operatives implementing the 'directives' of their political masters and mistresses. ${ }^{86}$

I am optimistic that securing high trust and professional accountability is possible if teachers collectively speak back to policies and processes that de-professionalise their work.

\footnotetext{
84 Fitzgerald, 'Remodelling Schools'.

85 These terms 'makeover' and 'takeover' draw on the analogy used in reality television that assumes that any intervention results in improved performance or appearance.

86 Wilfred Carr and Anthony Harnett, Education and the Struggle for Democracy (Buckingham, UK: Open University Press, 1996), 195.
} 